\title{
Associations between HIV Status Disclosure, Social Support, and Adherence to and Antiretroviral Therapy in Adults Patients with HIV/AIDS
}

\author{
Musta'inul Habibi'), Setyo Sri Rahardjo²), Bhisma Murti') \\ 1)Masters Program in Public Health, Universitas Sebelas Maret \\ 2)Faculty of Medicine, Universitas Sebelas Maret
}

Background: Antiretroviral therapy (ART) has been successful in increasing the life span and quality of life of people living with HIV. The success of antiretroviral treatment can be assessed from the patient's compliance in taking the drugs prescribed by the doctor at the right time and at the right dose. Disclosure of HIV status and social support are factors associated with adherence to antiretroviral therapy (ART). This study aims to estimate the magnitude of disclosure of HIV status and social support with antiretroviral therapy adherence to adult patients with HIV/AIDS with a meta-analysis study.

Subjects and Method: This was a systematic review and meta-analysis conducted using PRISMA flow diagrams. Article searches were conducted through journal databases including: Google Scholar, PubMed, Springer Link, Clinical key and ProQuest. The articles used in this study are articles that have been published from 2010-2021. The keywords to search for articles are as follows: "disclosing HIV and antiretroviral adherence", "Social Support or family support and antiretroviral adherence". The inclusion criteria were full text with crosssectional study design, articles in English, multivariate analysis with adjusted odds ratio.
Eligible articles were analyzed using the Revman 5.4 application.

Results: A meta-analysis of 9 observational studies showed that patients who disclosed their HIV status increased adherence to antiretroviral therapy 2.3 times compared to patients who did not disclose significantly $(\mathrm{aOR}=2.3695 \% \mathrm{CI}=1.75$ to $3.19 ; \mathrm{p}<0.001) . \mathrm{A}$ meta-analysis of 9 observational studies showed that patients who received social support significantly increased adherence to antiretroviral therapy 1.4 times compared to patients who did not have support $(\mathrm{aOR}=1.46$; $95 \% \mathrm{CI}=1.08$ to $1.97 ; \mathrm{p}=0.010$ ).

Conclusion: Disclosure of HIV status and social support improves adherence to antiretroviral therapy in adult patients with HIV/AIDS.

Keywords: Adherence, Antiretroviral therapy, HIV/AIDS, Disclosure of HIV status, Social support, Meta-analysis

\section{Correspondence:}

Musta'inul Habibi. Masters Program in Public Health. Universitas Sebelas Maret, Jl.Ir. Sutami 36A, Surakarta 57126, Central Java. Email: Mustainul87@gmail.com. Mobile: 085649959811.

Cite this as:

Habibi M, Rahardjo SS, Murti B (2021). Associations between HIV Status Disclosure, Social Support, and Adherence to dan Antiretroviral Therapy in Adults Patients with HIV/AIDS. J Epidemiol Public Health. 06(01): 112-124. https://doi.org/10.26911/jepublichealth.2021.06.01.11.

\section{(C) (D) Journal of Maternal and Child Health is licensed under a Creative Commons}

(c) EY NC SA Attribution-NonCommercial-ShareAlike 4.0 International License.

BACKGROUND
HIV or Human Immunodeficiency Virus is
a virus that infects cells of the immune
system, destroying or impairing their
function. HIV infection causes progressive

damage to the immune system, thus causing AIDS (WHO, 2015). HIV has attacked all parts of the world and is a global public health problem. Since the start of the epidemic, about 75.7 million 
people have been infected with HIV and about 32.7 million have died. In 2019, it is estimated that there will be 1.7 million new HIV cases, with a total of 38 million people living with HIV worldwide (UNAIDS, 2020)

UNAIDS reported that in June 2020, 26 million people with HIV had accessed antiretroviral therapy (ART). This has increased by 6.4 million people compared to 2019 (UNAIDS, 2020). People with HIV require Antiretroviral Therapy (ART) to slow HIV progression, reduce AIDS death rates and turn infection from a fatal disease to a more manageable chronic disease. Although antiretroviral treatment does not cure the disease, it can greatly help people infected with HIV by reducing opportunistic infections. Antiretroviral therapy (ART) has been successful in increasing the life span and quality of life of people living with HIV (Wasti et al., 2012).

The success of antiretro-viral treatment can be judged from the patient's compliance in taking the drugs prescribed by the doctor at the right time and at the right dose. Compliance with taking medication in HIV/AIDS patients includes accuracy in time, amount, dose, and the way individuals take their personal medications (Djoerban, 2010). Adherence to antiretroviral therapy (ART) is expected to be at least 95\%. Optimal adherence is required for all HIV-infected persons enrolled in chronic care services to follow the treatment plan (Ejigu et al., 2020). Optimal antiretro-viral therapy (ART) adherence helps to improve the health and well-being of people living with HIV/AIDS (PLWHA) because it reduces morbidity, mortality and slows the progression of HIV disease by suppressing viral replication. In addition, it can also reduce the risk of HIV transmission (Cohenet et al., 2011).
Based on a preliminary study (Abadiga et al., 2020) the adherence rate of antiretroviral therapy varies in different countries, including: in China $85.5 \%$, in Myanmar 84.0\%, in Northern Tanzania 71.0\% and in Ghana 62.2\%. Several researchers found that socio-demographic variables such as knowledge level and education level had a statistically significant effect on adherence to antiretroviral therapy (ART) (Tegegne et al., 2018). The level of adherence to antiretroviral therapy can be assessed based on the context of the population, and is moreover influenced by the behavior of PLWHA and related therapy service factors such as substance abuse, psychiatric problems, lack of social support, stigma, drug side effects, pill burden, poor quality of care, and inability to disclose HIV status (legesse et al., 2019).

Disclosure of HIV status and social support are factors associated with adherence to antiretroviral therapy (ART). Patients who disclose their HIV status to their family and others are almost four times more likely to adhere to ART compared to patients who do not disclose their HIV status on the grounds that they can take medication without fear in the presence of good social support and appropriate financial support from their family (Angelo et al. al., 2021).

As an achievement of the target 9595-95 by 2030 which has been set by UNAIDS to ensure successful treatment saves lives for millions of people with HIV/ AIDS. The systematic review and metaanalysis in this study synthesized evidence to provide information on clinical decisionmaking and policy in identifying the main health problems associated with antiretroviral therapy adherence, specifically related to disclosure of HIV/AIDS status and social support with antiretroviral therapy adherence. 


\section{SUBJECTS AND METHOD}

1. Study Design

The study design was a systematic review and meta-analysis, using PRISMA flow diagram guidelines. Article searches through journal databases include: Google Scholar, PubMed, Springer Link, Clinical key and ProQuest. The articles used in this study are articles that have been published from 2010-2021. The keywords to search for articles are as follows: "disclosing HIV and antiretroviral adherence", "Social Support or family support and antiretroviral adherence".

\section{Inclusion Criteria}

In this study, the inclusion criteria were full text articles using a cross-sectional study design, articles in English, and articles analyzed using multivariate with adjusted odds ratio. The research subjects were HIV/AIDS patients, the intervention was disclosed and the outcome supported was adherence to antiretroviral therapy.

\section{Exclusion Criteria}

Exclusion criteria in this study include articles published before 2010 and using languages other than English.

4. Operational Definition of Variables In formulating research problems here using PICO. The population is HIV/AIDS patients. Intervention is expressed and supported, with comparison that is not disclosed and not supported outcomes is adherence to antiretroviral therapy.

Disclosure of HIV Status is a person's ability to disclose information to family, friends, partners and counselors that he or she has HIV.

Social support is a comfort, attention, appreciation or assistance that individuals receive from other people or groups of people

Adherence to antiretroviral therapy is the time, amount, dose, and way individuals take their personal medications to treat HIV/AIDS infection in accordance with recommendations from health care providers with the aim of reducing the risk of resistance, improving the quality and survival of PLWHA, and reducing the risk of HIV transmission.

\section{Instruments}

An assessment of the quality of research articles was carried out using the Critical Appraisal of a Cross-Sectional Study (CEBMa, 2014).

\section{Data Analysis}

Articles were collected using the PRISMA diagram, and analyzed using the Review Manager 5.4 application by calculating effect size and heterogeneity to determine the combined research model and form the final result of the meta-analysis.

\section{RESULTS}

Research from the primary study related to the relationship between disclosure of HIV status and social support with adherence to antiretroviral therapy (ART) in adult patients with HIV/AIDS consisted of 16 articles from 2 continents, Asia and Africa. 1 study came from the Asian continent (Pakistan), 15 from Africa (Ethiopia, Ghana, Kenya, Sudan and the Democratic Republic of the Congo). Figure 1 shows the region of the articles taken according to the inclusion criteria. Furthermore, the researchers conducted an assessment of the quality of the article. The results showed that disclosure of HIV status and social support had a relationship with adherence to antiretroviral therapy. The search for articles was carried out using a database based on the PRISMA flow diagram in Figure 1. After assessing the quality of the study, 16 articles were divided into 2 categories according to the dependent variable. Of the 16 articles, there were 2 articles, each of which contained 2 articles that included 2 interventions, so that 9 articles for 
Habibi et al./ HIV Status Disclosure, Social Support, and Adherence to dan Antiretroviral Therapy

disclosure of HIV status and 9 articles included in the quantitative synthesis

process of the meta-analysis were analyzed using RevMan 5.4.

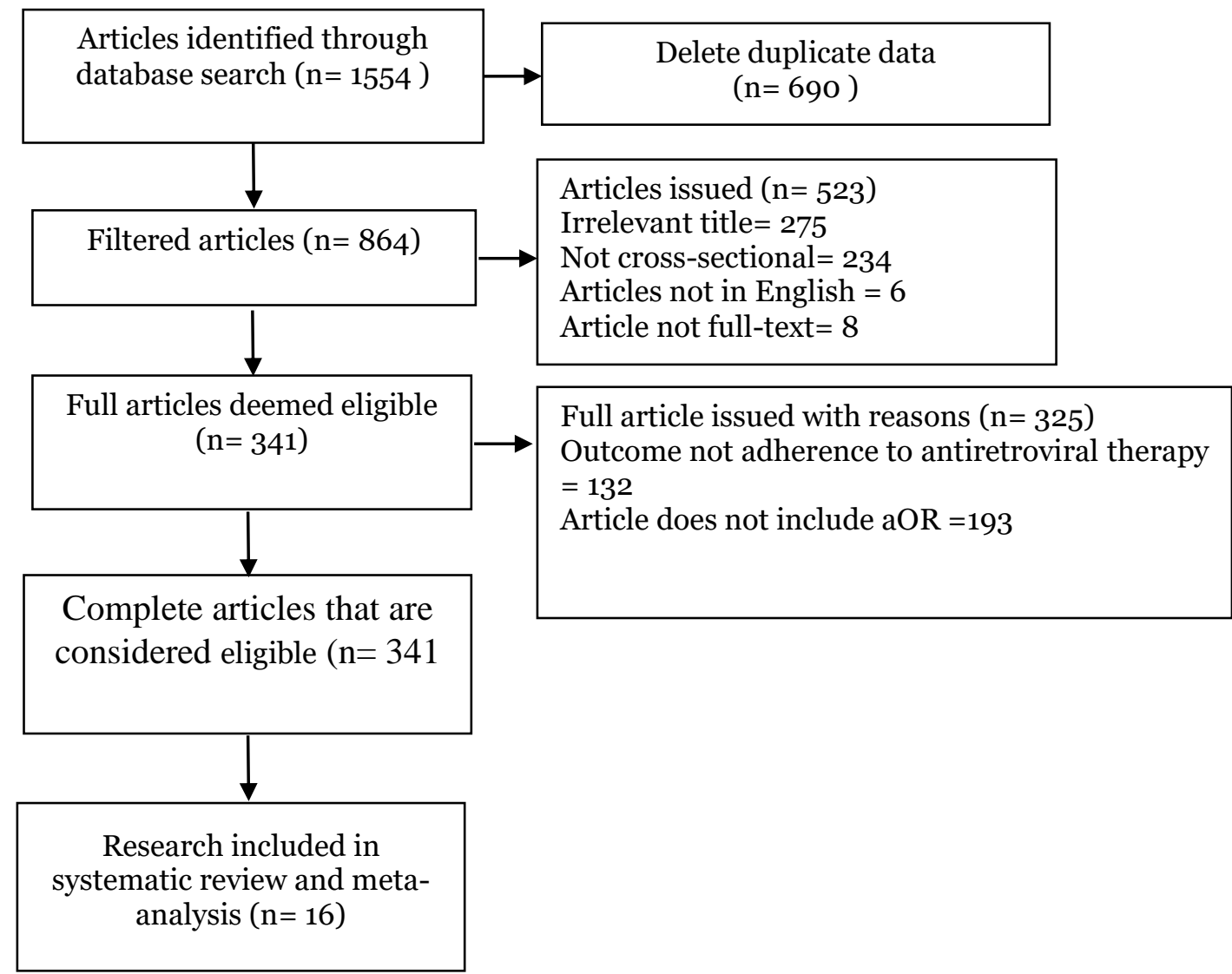

Figure 1. PRISMA flow diagram

\section{Research Quality Assessment}

Assessment of research quality uses a critical appraisal tool from the center for evidence-based management which can be seen (table 1).

The criteria for evaluating articles with a cross sectional study design are as follows:

1. Does the research clearly address the question/problem focus?

2. Is the research design appropriate to answer the research question?

3. Is the method of selecting research subjects clearly explained?

4. Does the method of obtaining the sample lead to bias?

5. Is the sample of the subject representtative of the population to which the findings will be referred?
6. Was the sample size based on pre-study statistical power considerations?

7. Was a satisfactory response rate achieved?

8. Does the measurement (questionnaire) tend to be valid and reliable?

9. Was statistical significance assessed?

10. Is the confidence interval given the primary outcome?

11. Could there be confounding factors that have not been taken into account?

12. Can the results be applied?

After assessing the quality of the study, 16 articles were divided into 2 categories according to the dependent variable. Of the 16 articles, there were 2 articles, each of which contained 2 articles, each of which included 2 interventions, so that 9 articles 
Habibi et al./ HIV Status Disclosure, Social Support, and Adherence to dan Antiretroviral Therapy

for disclosure of HIV status and 9 articles

process of meta-analysis were analyzed included in the quantitative synthesis using RevMan 5.4.

Table 1. Assessment of the quality of cross-sectional design research penelitian

\begin{tabular}{|c|c|c|c|c|c|c|c|c|c|c|c|c|c|}
\hline \multirow[t]{2}{*}{ Primary Study } & \multicolumn{13}{|c|}{ Criteria } \\
\hline & $\mathbf{1}$ & 2 & 3 & 4 & 5 & 6 & 7 & 8 & 9 & 10 & 11 & 12 & Total \\
\hline Abadiga et al. (2020) & 1 & 1 & 1 & 1 & 1 & 1 & 1 & 1 & 1 & 1 & 1 & 1 & 12 \\
\hline Ali et al. (2018) & 1 & 1 & 1 & 1 & 1 & 1 & 1 & 1 & 1 & 1 & 1 & 1 & 12 \\
\hline Angelo et al. (2021) & 1 & 1 & 1 & 1 & 1 & $\mathrm{O}$ & 1 & 1 & 1 & 1 & 1 & 1 & 11 \\
\hline Basha et al. (2021) & 1 & 1 & $\mathrm{O}$ & 1 & 1 & 1 & 1 & 1 & 1 & 1 & 0 & 1 & 10 \\
\hline Billoro et al. (2018) & 1 & 1 & 1 & 1 & 1 & 1 & $\mathrm{O}$ & 1 & 1 & 1 & 1 & 1 & 11 \\
\hline Biomndo et al. (2021) & 1 & 1 & 1 & 1 & 1 & 1 & 1 & 1 & 1 & 1 & 1 & 1 & 12 \\
\hline Debito et al. (2014) & 1 & 1 & 1 & $\mathrm{O}$ & 1 & 1 & 1 & 1 & 1 & 1 & 0 & 1 & 10 \\
\hline Gebertsadik et al. (2020) & 1 & 1 & 1 & 1 & $\mathrm{O}$ & $\mathrm{O}$ & 1 & 1 & 1 & 1 & 1 & 1 & 10 \\
\hline Gebreagziabher et al. (2020) & 1 & 1 & 1 & 1 & 1 & 1 & 1 & 1 & 1 & 1 & o & 1 & 11 \\
\hline Ibrahim et al. (2014) & 1 & 1 & 1 & 1 & 1 & 1 & 1 & 1 & 1 & 1 & 1 & 1 & 12 \\
\hline Masumari et al. (2014) & 1 & 1 & 1 & 1 & 1 & 1 & O & 1 & 1 & 1 & 1 & 1 & 11 \\
\hline Molla et al. (2018) & 1 & 1 & 1 & 1 & 1 & 1 & 1 & 1 & 1 & 1 & 1 & 1 & 12 \\
\hline Negash et al. (2016) & 1 & 1 & 1 & o & 1 & 1 & 1 & 1 & 1 & 1 & 1 & 1 & 11 \\
\hline Obirikorang et al. (2013) & 1 & 1 & 1 & 1 & 1 & 1 & 1 & 1 & 1 & 1 & 1 & 1 & 12 \\
\hline Tarekegn et al. (2019) & 1 & 1 & 1 & 1 & $\mathrm{O}$ & 1 & 1 & 1 & 1 & 1 & 1 & 1 & 11 \\
\hline Tiyou et al.2010) & 1 & 1 & 1 & 1 & 1 & 1 & 1 & 1 & 1 & 1 & 1 & 1 & 12 \\
\hline
\end{tabular}

1. Relationship disclosure status HIV with adherence to antiretroviral therapy

\section{a. Forest plot}

Interpretation of the results of the metaanalysis process can be seen through the forest plot. From Figure 2, it can be seen that there is low heterogeneity $\left(\mathrm{I}^{2}=34 \% ; \mathrm{p}=\right.$ 0.15), so the forest plot data analysis used the fixed effect model. Then it was found that there was a relationship between disclosure of HIV status and adherence to antiretroviral therapy, patients who disclosed their HIV status could increase adherence to antiretroviral therapy 2.4 times compared to patients who did not disclose significantly $(\mathrm{aOR}=2.36 ; 95 \% \mathrm{CI}=$ 1.75-3.19; $\mathrm{p}<0.001$ ).

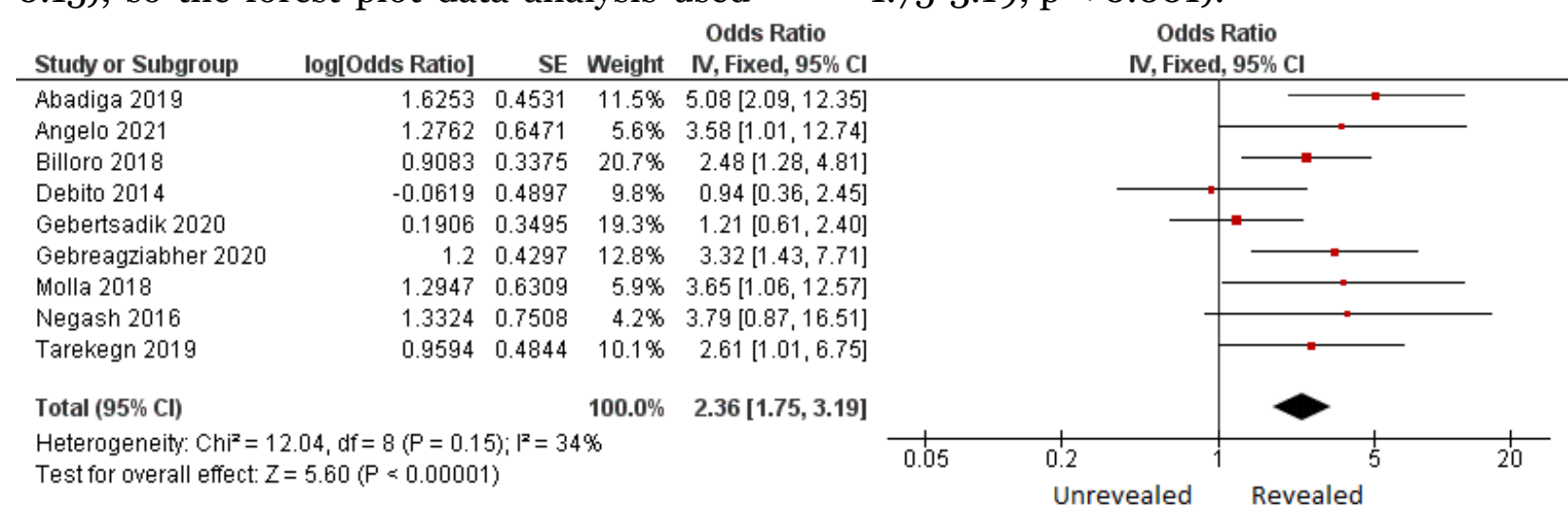

\section{Figure 2. Forest plot of relationship disclosure status of HIV} with adherence to antiretroviral therapy

\section{b. Funnel plot}

A funnel plot is a plot that depicts the approximate size of the effect of each study on the estimate of its accuracy which is usually the standard error. Based on Figure 3 , it shows that there is a publication bias 
which is indicated by the asymmetry of the right and left plots where there are 7 plots on the right and 2 plots on the left. The plot on the left of the graph appears to have a standard error between 0.6 and 0.2 and the plot on the right has a standard error between 0.8 and 0.2. Bias also occurs from the imbalance in the distance between studies on both the right and left sides of the Funnel plot.

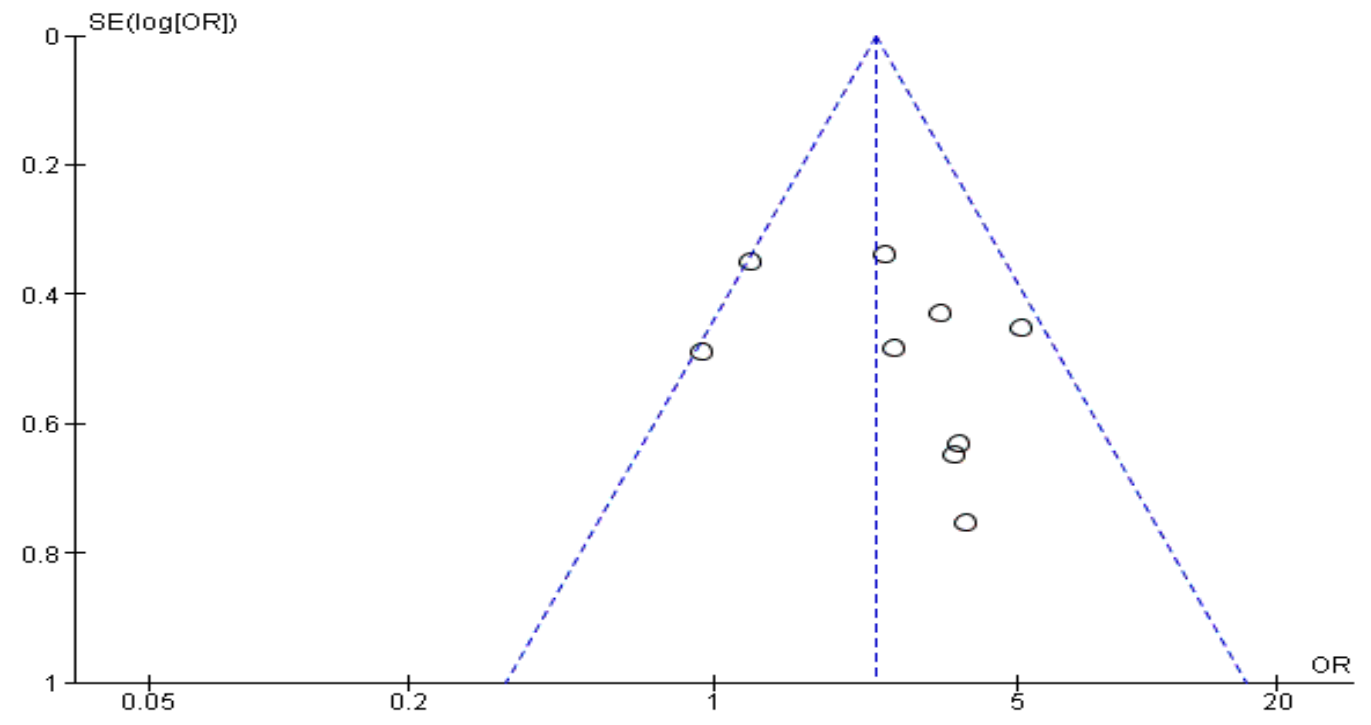

Figure 3. Funnel plot of the relationship between HIV status Disclosure and antiretroviral therapy adherence

\section{Relationship social support with adherence to antiretroviral therapy}

\section{a. Forest plot}

Interpretation of the results of the metaanalysis process can be seen through the forest plot. From Figure 4 it can be seen that there is high heterogeneity $\left(\mathrm{I}^{2}=57 \%\right.$; $\mathrm{p}=0.020$ ), so the forest plot data analysis uses a random effect model. Then it was found that there was a relationship between social support and adherence to antiretroviral therapy, patients who received social support could increase adherence to antiretroviral therapy 1.4 times compared to those who did not have support significant- ly $(\mathrm{aOR}=1.46 ; 95 \% \mathrm{CI}=1.08$ to $1.97 ; \mathrm{p}<$ 0.001).

\section{b. Funnel plot}

A funnel plot is a plot that depicts the approximate size of the effect of each study on the estimate of its accuracy which is usually the standard error. Figure 5 shows no publication bias as indicated by the symmetry of the right and left plots where there are 4 plots on the right and 4 plots on the left. The plot on the left of the graph appears to have a standard error between 0.4 and 0.2 and the plot on the right has a standard error between 0.4 and 0.2 , there is no bias. 
Habibi et al./ HIV Status Disclosure, Social Support, and Adherence to dan Antiretroviral Therapy

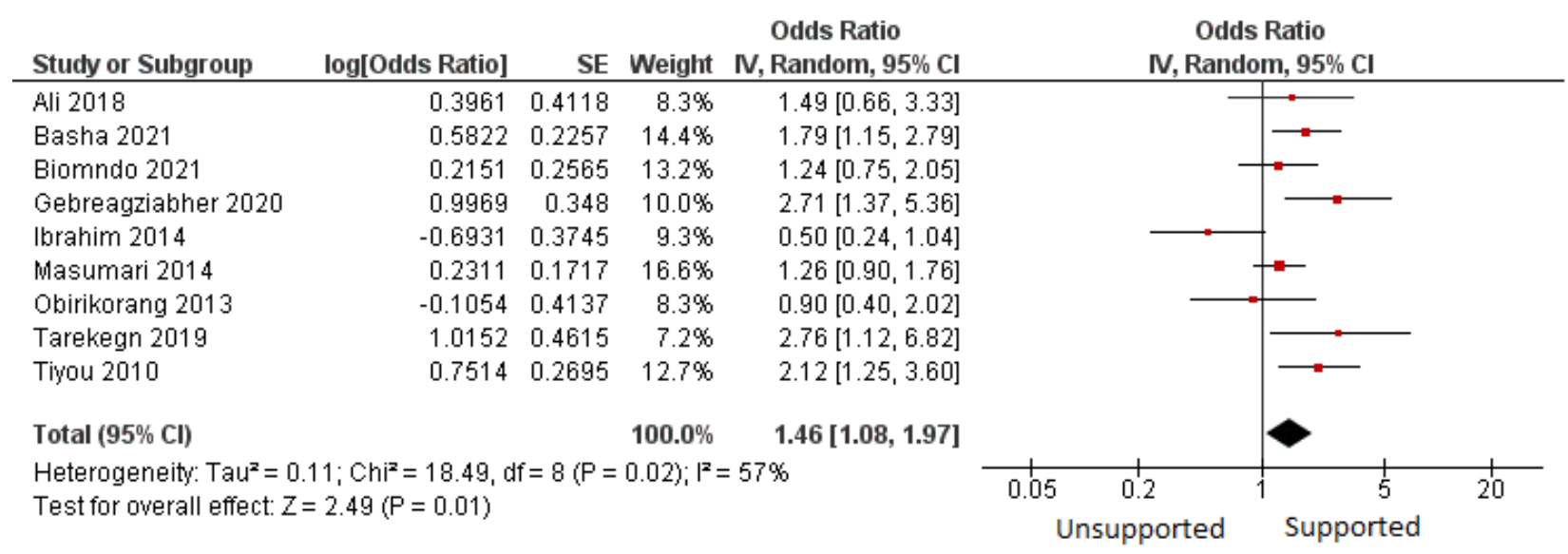

Figure 4. Forest plot of social support relationships with adherence to antiretroviral therapy

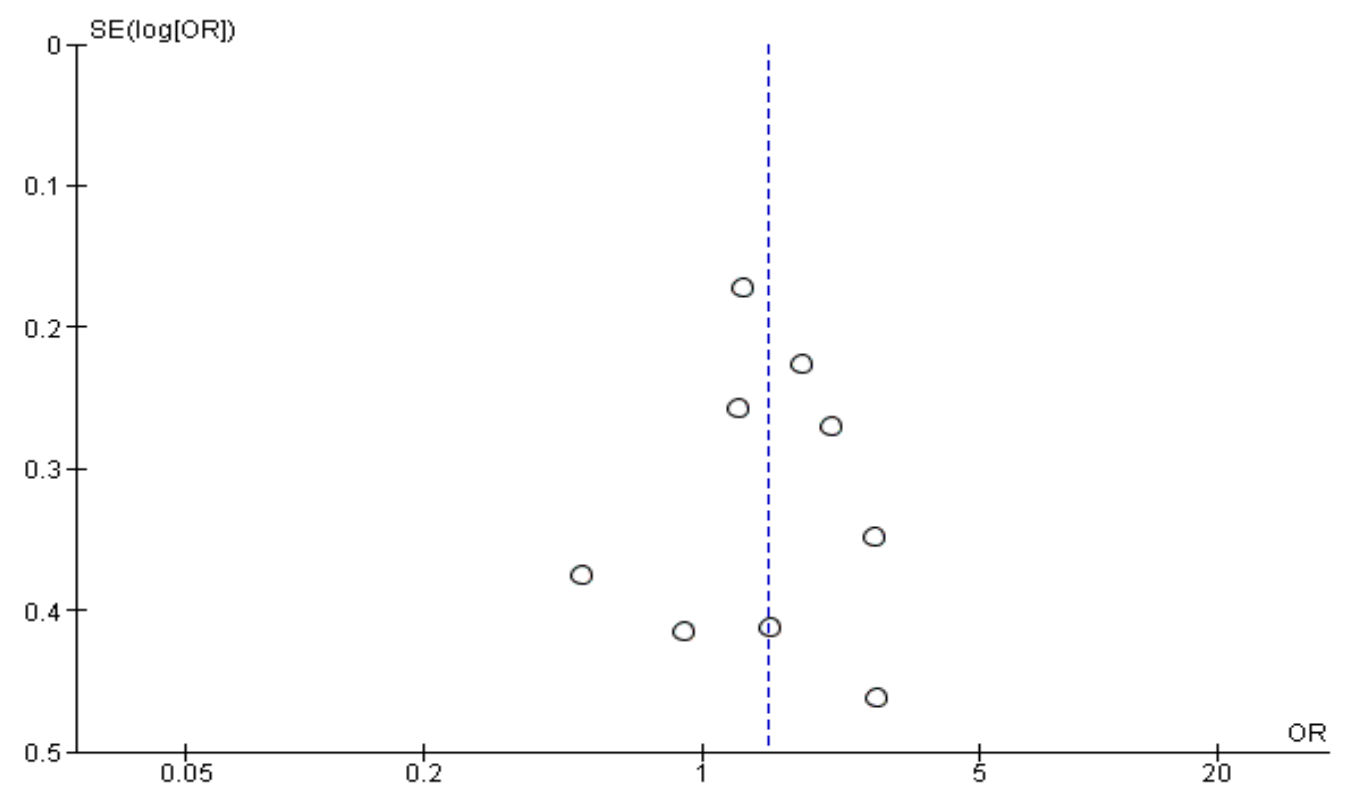

Figure 5. Funnel plot of social support relationships with adherence to antiretroviral therapy

\section{DISCUSSION}

This systematic review research and metaanalysis raised the theme of the relationship between disclosure of HIV status and social support with adherence to antiretroviral therapy in adult patients with HIV/ AIDS. The independent variables were disclosure of HIV status and social support and the dependent variable was adherence to antiretroviral therapy. The intervention was designed to improve adherence to antiretroviral therapy with a cross-sectional study design. Research on adherence to antiretroviral therapy is considered important because it slows the progression of HIV and reduces the death rate from AIDS worldwide. According to Gebreagziabher et al. (2020) ART adherence assessment helps identify key health issues related to ART adherence and for policy makers working in the HIV/AIDS field for proper planning and implementation.

In this systematic review, there are 9 intervention studies identified worldwide 
from 2010 to 2021. This study analyzes articles that use relationship measures from the results of multivariate adjusted Odds Ratio (aOR) analysis. The results of the systematic review and meta-analysis are presented in the form of forest plots and funnel plots. A forest plot is a diagram that shows an overview of the information from each of the studies examined in the metaanalysis and estimates of the overall results (Murti, 2018a). The forest plot also shows visually the magnitude of variation (heterogeneity) between study results. The funnel plot shows the relationship between the effect size of study $i$ and the sample size or standard error of the effect size of the various studies studied (Murti, 2018a). The possibility of publication bias in the funnel plot can be seen from the asymmetry of the number of studies on the right and left sides.

Several previous studies such as by Abadiga et al. (2020), Ali et al. (2018), Basha et al. (2021), Biomndo et al. (2021) and Obirikorang et al. (2013) reported increasing adherence to antiretroviral therapy through HIV/AIDS status disclosure and social support resulted in a significant value associated with adherence to antiretroviral therapy.

According to Gebreagziabher et al. (2020) adherence can be improved by providing health education to ART users and the entire community during special meetings and conferences on the importance of social support. Most of the reasons for non-adherence are due to lack of awareness, so awareness creation should be strengthened to increase adherence to ART among HIV/AIDS patients.

Adherence to antiretroviral therapy (ART) is one of the factors that has the potential to alter outcomes for patients with HIV. To achieve the goals of ART, maximal and long-lasting viral suppression and successful HIV therapy require 95\% adherence Billoro et al. (2018).

\section{Disclosure of HIV status with adhe- rence to antiretroviral therapy}

There are 9 research articles with a crosssectional study design as a source of metaanalysis of the relationship between disclosure of HIV status and adherence to antiretroviral therapy in adult patients with HIV/AIDS. The results of the meta-analysis on the forest plot showed that patients who disclosed their HIV status could increase treatment adherence 2.4 times compared to patients who did not disclose significantly $(\mathrm{aOR}=2.36 ; 95 \% \mathrm{CI}=1.75$ to $3.19 ; \mathrm{p}=$ 0.010). This meta-analysis study provides evidence to support disclosure of HIV status to improve adherence to antiretroviral therapy in HIV/AIDS patients.

The results of this study are supported by Angelo and Alemayehu, (2021) conducted at Gebre-Tsadik Shawo General Hospital (GTSGH) and Mizan Tepi University Teaching, Southwest Ethiopia which stated that disclosure was associated with adherence to antiretroviral therapy 3.58 times compared to patients who did not expressed $(\mathrm{aOR}=3.58 ; 95 \% \mathrm{CI}=1.01$ to 12.73; $\mathrm{p}=0.050)$. In addition, research by molla et al. (2018) stated that patients who disclosed their HIV status to their partners were 3.7 times more likely to comply than those who did not $(\mathrm{aOR}=3.65 ; 95 \% \mathrm{CI}=$ 1.06 to 12.61). The conclusion of this study was that ART adherence was found to be low compared to WHO standards, having knowledge of HIV treatment and disclosing HIV status to partners and CD4 cell count $500 \mathrm{~mm} 3$ were significantly associated with good ART adherence.

The results of this study are also supported by a previous meta-analysis conducted by Dessie et al. (2019) stated that disclosure has a positive impact on adherence to ART in adult patients living 
with HIV. Patients who disclosed were 1.64 times more likely to have good adherence to ART compared with those who did not disclose significantly $(\mathrm{OR}=1.64 ; 95 \% \mathrm{CI}=$ 1.11 to 2.42). The conclusion of this study was to find a statistically significant positive effect of disclosure status on ART adherence in adult patients living with HIV in Ethiopia. Another study conducted by Billoro et al. (2018) Patients who disclosed their use of ART were 2.48 more likely to adhere to the regimen compared with participants who did not disclose $(\mathrm{aOR}=2.48$; $95 \% \mathrm{CI}=1.28$ to 4.79 ).

Thus considering the benefits and positive impact of disclosure of HIV status related to adherence to antiretroviral therapy, the results of this meta-analysis support the efforts of self-disclosure among people living with HIV/AIDS, encouraging a supportive social environment for disclosure that is very helpful in improving adherence to antiretroviral therapy. Because those who do not disclose their HIV status can cause problems in consuming inconsistent antiretroviral therapy drugs, resulting in drug resistance and causing opportunistic infections. Therefore, optimal adherence to antiretroviral therapy is very important to ensure appropriate and consistent levels of ARV drugs are taken.

\section{Social support with antiretroviral therapy adherence}

There are 9 research articles with a crosssectional study design as a source of metaanalysis of the relationship between social support and adherence to antiretroviral therapy in adult patients with HIV/AIDS. The results of the meta-analysis on the forest plot showed that patients who received social support could increase antiretroviral adherence 1.46 times compared to patients who did not receive support significantly $(\mathrm{aOR}=1.46 ; 95 \% \mathrm{CI}=1.08$ to 1.97; $\mathrm{p}=0.010$ ). This meta-analysis pro- vides evidence to support that social support can improve adherence to antiretroviral therapy in HIV/AIDS patients.

The results of this study are in line with the research of Obirikorang et al. (2013) conducted in March and May 2013 at the Upper West Regional Hospital located in the southern part of the capital Wa, with a total of 201 subjects. Stating that family support has treatment adherence 0.9 times compared with patients who did not have significant family support $(\mathrm{aOR}=0.9 ; 95 \% \mathrm{CI}: 0.40$ to $1.97=0.76)$, social support could positively increase adherence to antiretroviral therapy

This study was supported by Gebreagziabher et al. (2020) at Tigray East General Hospital, Northern Ethiopia, patients with social support were 2.7 times more likely to adhere to ART than patients without social support significantly $(\mathrm{aOR}=2.71$; 95\% $\mathrm{CI}=1.37$ to $9.74 ; \mathrm{p}=0.017$ ). In addition, the research conducted by Basha et al. (2021) at the North Shewa Zone Selected Hospital, stated that poor adherence to antiretroviral drugs was strongly associated with poor social support $(\mathrm{aOR}=2.06 ; 95 \%$ $\mathrm{CI}=1.36$ to 3.13 ). Another study conducted by Tiyou et al. (2010) stated that patients who received family support were 2 times more likely to comply than those who did not receive family support as an independent predictor of overall adherence (dose, time and food $)(\mathrm{aOR}=2.12 ; 95 \% \mathrm{CI}=1.25$ to 3.59).

The results of this meta-analysis show the importance of social support for HIV/ AIDS patients during treatment. Social support can improve the psychological well-being of HIV/AIDS patients. HIV patients who receive better emotional, instrumental and rewarding support, such as family who provide, care, motivation and full support for treatment, patients will feel comfortable and feel confident so they are 
obedient in taking anti-retroviral drugs according to the dose and schedule provided by health care providers. Social support is a positive outcome for better adherence to ART, therefore the involvement of family, partners, friends and the community is needed during the treatment process.

\section{AUTHOR CONTRIBUTION}

Musta'inul habibi is the main researcher who chooses the topic, conducts a search for data collection in this study. Setryo Sri Rahardjo and Bhisma Murti conducted data analysis and review of research documents.

\section{FUNDING AND SPONSORSHIP}

This study is self-funded.

\section{CONFLICT OF INTEREST}

There is no conflict of interest in this study.

\section{ACKNOWLEDGEMENT}

The researcher would like to thank all those who have helped in the preparation of this article and also thank the database providers PubMed, Science Direct, and Google Scholar.

\section{REFERENCES}

Abadiga M, Hasan T, Mosisa G, Abdisa E (2020). Adherence to antiretroviral therapy and associated factors among Human immunodeficiency virus positive patients accessing treatment at Nekemte referral hospital, West Ethiopia 2019. PLoS ONE, 15(5) : 114. doi: 10.1371/journal.pone.0232703 .

Ali B, Nisar N, Nawab F (2018). Adherence to antiretroviral therapy in HIV-positive, male intravenous drug users in Pakistan. Eastern Mediterranean Health J. 24(3): 237-242. doi:10.267-
19/2018.24.3.237.

Angelo AT, Alemayehu DS (2021). Adherence and its associated factors among adult HIV infected patients on antiretroviral therapy in South Western Ethiopia, 2020. Patient Preference and Adherence, 15 : 299-308. doi: 10.2147/PPA.S298594.

Basha EA, Derseh BT, Wubetu AD, Engidaw N, Gizachew KD (2021). Factors affecting social support status of people living with HIV/AIDS at Selected Hospitals of North Shewa Zone, Amhara Region, Ethiopia. J Trop Med. doi: 10.115/2021/6695298.

Billoro B, Mamo G, Jarso H (2018). Adherence to antiretroviral therapy and associated factors among HIV infected patients in Nigist Eleni Mohammed Memorial General Hospital Hossana, Southern Ethiopia. AIDS ClinRes, o9(08). doi: 10.4172/21556113.1000774 .

Biomndo BC, Bergmann A, Lahmann N, Atwoli L (2021). Intimate partner violence is a barrier to antiretroviral therapy adherence among HIV-positive women: Evidence from government facilities in Kenya. PLoS ONE, 16 (4): 1-18. doi: 10.1371/journal.pone.0249813.

Birhanu M, Abegaz T, Fikre R (2019). Magnitude and factors associated with optimal complementary feeding practices among children aged 6-23 months in Bensa District, Sidama Zone, South Ethiopia. Ethiopian J Health Sci. 29(2): 153-164. doi: 10.4314/ejhs.v29i2.2.

Brasher LV (2008) Aplikasi Klinis Patofisiologi. Jakarta: EGC.

CEBM (2014). Checklist for the Critical Appraisal of a Controlled Study. (10): 12.

Cochrane (2011). RevMan 5.3 User Guide. 
Habibi et al./ HIV Status Disclosure, Social Support, and Adherence to dan Antiretroviral Therapy

Debito T, Deyno S (2014). Rate and predictors of adherence to antiretroviral therapy among clients on antiretroviral therapy at Tepi Health Center, South-west Ethiopia. Sci Tech Arts Res J. 3(3): 93. doi: 10.4314/star.v3i3.15.

Departemen Kesehatan RI (2003) HIV/ AIDS dan Pencegahannya. Jakarta: Ditjen PP \& PL.

Dessie G, Wagnew F, Mulugeta H, Amare D, Jara D, Leshargie C T, Negesse A, Rayasam S. and Burrowes S. (2019) 'The effect of disclosure on adherence to antiretroviral therapy among adults living with HIV in Ethiopia: A systematic review and meta-analysis', BMC Infectious Diseases, 19(1), 1-8. doi: 10.1186/s12879-019-4148-3.

Devito JA (2011). Komunikasi antar manusia (Communication between humans). $5^{\text {th }}$ edn. Pamulang-Tangerang Selatan: Karisma Publishing Group.

Djoerban, Djauzi. (2009) HIV/AIDS di Indonesia (HIV/AIDS in indonesia). Dalam: Buku Ajar Ilmu Penyakit Dalam, Jilid III. V. Jakarta: Departemen Ilmu Penyakit Dalam FKUI.

Ejigu M, Desalegn Z, Mulatu B, Mosisa G (2020). Adherence to combined antiretroviral therapy and associated factors among people living with HIV attending nekemte specialized hospital. Oromia Ethiopia: A cross-sectional study. HIV/AIDS - Res Palliative Care. 12: 97-106. doi: 10.2147/HIV.S239995.

Gebreagziabher TT, Woldemariam GT (2020). Antiretroviral treatment adherence and determinant factors among adult people infected with human immunodeficiency virus in eastern tigray general hospitals, northern ethiopia 2019. HIV/AIDS Research and Palliative Care. 12: 497-
505. doi: 10.2147/HIV.S273917.

Gebretsadik GG, Gebretnsae H, Ftwi M, Tesfahunegn A (2020). Alarm clockbased reminder for improving low adherence on option B plus antiretroviral therapy among HIV positive pregnant and lactating mothers in Northern Ethiopia. HIV/AIDS- Res Palliative Care. 12: 687-695. doi: 10.2147/HIV.S261420.

Hanif H, Francisco, Bastos, Malta M, Bertoni N, Surkan PJ, Winch PJ, Kerrigan D (2013). Individual and contextual factors of influence on adherence to antiretrovirals among people attending public clinics in Rio de Janeiro, Brazil. BMC Public Health, 13(1). doi: 10.1186/1471-245813-574.

Hunter JE, Jensen JL, Rodgers R (2014). The control group and meta-analysis. J Methods Measurement Soc Sci. 6(1): 3-21. doi: 10.2458/azu_jmmss.v5i1.18302.

Huynh AK, Kinsler JJ, William E, Cunningham, Sayles JN (2013). The role of mental health in mediating the relationship between social support and optimal ART adherence. AIDS Care Psychological and Socio-Medical Aspects of AIDS/HIV. 25(9): 11791184. doi: 10.1080/09540121.2012.752787.

Ibrahim Y, Sutan R, Abdul Latif K, Al-Abed AAA, Amara A, Adam I (2014). Poor adherence to antiretroviral therapy and associated factors among people living with HIV in Omdurman City Sudan. Malaysian J Public Health Med. 14(1): 90-101.

King LA (2012) Psikologi Umum: Sebuah Pandangan Apresiatif Buku 2 (General Psychology: An Appreciative View Book 2). Jakarta: Salemba Humanika. Letta S, Demissie A, Oljira L, Dessie Y 
(2015). Factors associated with adherence to Antiretroviral Therapy (ART) among adult people living with HIV and attending their clinical care, Eastern Ethiopia HIV/AIDS. BMC Int Health Human Rights. 15(1): 1-7. doi: 10.1186/s12914-015-0071-x.

Liliweri A (2017). Komunikasi Antar Personal (Interpersonal Communication). Jakarta: kencana.

Lobis YB, Murti B, Prasetya H (2020). Influences of peer support group and psychosocio- economic determinants on treatment compliance in HIV/ AIDS patients in Sragen, Central Java. 05: 348-358. doi:10.26911/the7thicph.02.59.

Mikolajewicz N, Komarova SV (2019). Meta-analytic methodology for basic research: A practical guide. Frontiers in Physiology, 10(MAR). doi: 10.3389/fphys.2019.00203.

Molla AA, Gelagay AA, Mekonnen HS, Teshome DF (2018). Adherence to antiretroviral therapy and associated factors among HIV positive adults attending care and treatment in University of Gondar Referral Hospital, Northwest Ethiopia. BMC Infectious Dis. 18(1): 1-8. doi: 10.1186/s12879018-3176-8.

Murti B (2018a) Prinsip Dan Metode Riset Epidemiologi. $5^{\text {th }}$ Ed. Karanganyar: Program Studi Ilmu Kesehatan Masyarakat.

Musumari PM, Wouters E, Kayembe PK, Nzita MK, Mbikayi SM, Suguimot SP, Techasrivichien T, et al. (2014). Food insecurity is associated with increased risk of non-adherence to antiretroviral therapy among HIV-infected adults in the Democratic Republic of Congo: A cross-sectional study. PLoS ONE, 9(1): 1-10.doi: 10.1371/journal pone.008532 7 .
Negash E, Wakgari N, Wasie B, Edris M, Bekele G (2016). Adherence to antiretroviral therapy and its associated factors among HIV positive patients in Nekemte public health institutions, West Ethiopia. HIV and AIDS Review, 15(3): 116-121. doi: 10.1016/j.hivar.2016.04.004.

Nieuwenstein MR, Wierenga T, Morey RD, Wicherts JM, Blom TN, Wagenmakers EJ, Rijn HV (2015). On making the right choice: A meta-analysis and large-scale replication attempt of the unconscious thought advantage. Judgment and Decision Making, 10(1): 1-17.

Nikolakopoulou A, Chaimani A, Veroniki AA, Vasiliadis HS, Schmid CH, Salanti $\mathrm{G}$ (2014). Characteristics of networks of interventions: A description of a database of 186 published networks. PLoS ONE. 9(1): e86754. doi:10.1371/journal.pone.oo86754.

Nindiyastuti NAI, Prasetya H, Murti B (2018). Determinants of mobile voluntary counselling and testing of HIV use among gay in Surakarta Central Java. J Health Promot Behav. 3(3): 155-165. doi:10.26911/thejhpb.2018.03.03.03.

Nursalam K (2009) Asuhan Keperawatan pada Pasien Terinfeksi HIV/AIDS (Nursing Care for HIV/AIDS-Infected Patients). Jakarta: Salemba Medika.

Obirikorang C, Selleh PK, Abledu JK, Fofie CO (2013). Predictors of adherence to antiretroviral therapy among HIV/ AIDS patients in the Upper West Region of Ghana. ISRN AIDS. 2013: 873939. https://doi.org/10.1155/2013/873939.

Paldam M (2015). Meta-analysis in a nutshell: techniques and general findings Economics. 9: 1-15. doi: 10.5018/economics-ejournal.ja.2015- 
Habibi et al./ HIV Status Disclosure, Social Support, and Adherence to dan Antiretroviral Therapy

11.

Palm D (2020). Seizing the Square, Berlin, Boston: De Gruyter Oldenbourg. doi: 10.1515/9783110682601.

Prasetyawati AE (2011). Ilmu kesehatan Masyarakat (Public health science). Yogyakarta: Nuha Medika.

Sarafino EP (2011). Health psychology: biopsychosocial interactions, in John Wiley \& Sons, I. (ed.). Amerika Serikat.

Sedgwick P (2013). Meta-analyses: How to read a funnel plot. BMJ. 346: f1342. https://doi.org/10.1136/bmj.f1342.

Tarekegn M, Baru A, Seme A (2019). Levels of option $\mathrm{B}+$ ART drugs adherence and associated factors among pregnant women following ART services at public health facilities of East Shawa Zone, Oromia, Ethiopia. Sex Reprod Healthc. 22: 100459. https://doi.org/10.1016/j.srhc.2019.100459.

Tegegne AS, Ndlovu P, Zewotir T (2018). Factors affecting first month adherence due to antiretroviral therapy among HIV-positive adults at Felege Hiwot Teaching and Specialized Hos- pital north-western Ethiopia; a prospective study. BMC Infect Dis. 18(1): 1-11. doi: 10.1186/s12879-018-2977o.

Tiyou A, Belachew T, Alemseged F, Biadgilign S (2010). Predictors of adherence to antiretroviral therapy among people living with HIV/AIDS in resourcelimited setting of Southwest Ethiopia. AIDS Res Ther. 7: 39. https://doi.org/10.1186/1742-6405-7-39.

Utomo WPB, Laksmiwati H (2019). Hubungan harga diri dengan pengungkapan diri pada siswa-siswi pengguna jejaring sosial instagram di SMA Negeri 1 Gedangan Character: Jurnal Penelitian Psikologi. 6(1).

WHO (2006). Antoretroviral Therapy for HIV Infection in Adults and, Adolescents Recommendation for a Public Health Approach - 2006 Revision. Geneva: WHO.

Woodall GM (2014). Graphical depictions of toxicological data in encyclopedia of toxicology: Third Edition. Elsevier. 786-795. doi: 10.1016/B978-0-12-386454-3.01051-4. 